\title{
PDGFRa up-regulation mediated by Sonic Hedgehog pathway activation leads to BRAF inhibitor resistance in melanoma cells with BRAF mutation
}

\author{
Francesco Sabbatino ${ }^{1,3,4, *}$, Yangyang Wang ${ }^{1,3, *}$, Xinhui Wang ${ }^{1,3}$, Keith T. Flaherty ${ }^{2,3}$, \\ Ling Yư ${ }^{5,7}$, David Pepin ${ }^{1,3}$, Giosue' Scognamiglio ${ }^{5,8}$, Stefano Pepe ${ }^{4}$, John M.

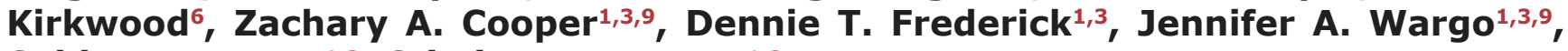 \\ Soldano Ferrone ${ }^{1,3}$, Cristina R. Ferrone ${ }^{1,3}$ \\ ${ }^{1}$ Department of Surgery, Massachusetts General Hospital, Boston, MA \\ 2 Department of Medical Oncology, Massachusetts General Hospital, Boston, MA \\ ${ }^{3}$ Harvard Medical School, Boston, MA \\ ${ }^{4}$ Department of Clinical and Molecular Oncology and Endocrinology, University of Naples "Federico II", Naples, Italy \\ ${ }^{5}$ Department of Surgery, University of Pittsburgh Cancer Institute, University of Pittsburgh, Pittsburgh, Pittsburgh, PA \\ ${ }^{6}$ Department of Medicine, University of Pittsburgh Cancer Institute, University of Pittsburgh, Pittsburgh, Pittsburgh, PA \\ ${ }^{7}$ Institute for Clean Energy \& Advanced Materials, Southwest University, Chongqing, P.R. China \\ ${ }^{8}$ Pathology Unit, Istituto Nazionale Tumori Fondazione G. Pascale, Naples, Italy \\ ${ }^{9}$ Department of Surgical Oncology, University of Texas MD Anderson Cancer Center, Houston, TX \\ * These authors contributed equally to this work \\ Correspondence to: Soldano Ferrone, email: sferrone@partners.org
}

Keywords: BRAF inhibitor resistance, PDGFRa up-regulation, PDGFRa inhibitors, melanoma, sonic hedgehog pathway, LDE225.

Received: February 13,2014 Accepted: March 31, $2014 \quad$ Published: March 31, 2014

This is an open-access article distributed under the terms of the Creative Commons Attribution License, which permits unrestricted use, distribution, and reproduction in any medium, provided the original author and source are credited.

\section{ABSTRACT:}

Control of BRAF(V600E) metastatic melanoma by BRAF inhibitor (BRAF-I) is limited by intrinsic and acquired resistance. Growth factor receptor up-regulation is among the mechanisms underlying BRAF-I resistance of melanoma cells. Here we demonstrate for the first time that PDGFRa up-regulation causes BRAF-I resistance. PDGFRa inhibition by PDGFRa-specific short hairpin (sh)RNA and by PDGFRa inhibitors restores and increases melanoma cells' sensitivity to BRAF-I in vitro and in vivo. This effect reflects the inhibition of ERK and AKT activation which is associated with BRAF-I resistance of melanoma cells. PDGFRa up-regulation is mediated by Sonic Hedgehog Homolog (Shh) pathway activation which is induced by BRAF-I treatment. Similarly to PDGFRa inhibition, Shh inhibition by LDE225 restores and increases melanoma cells' sensitivity to BRAF-I. These effects are mediated by PDGFRa down-regulation and by ERK and AKT inhibition. The clinical relevance of these data is indicated by the association of PDGFRa up-regulation in melanoma matched biopsies of BRAF-I $+/$ - MEK inhibitor treated patients with shorter time to disease progression and less tumor regression. These findings suggest that monitoring patients for early PDGFRa up-regulation will facilitate the identification of those who may benefit from the treatment with BRAF-I in combination with clinically approved PDGFRa or Shh inhibitors.

\section{INTRODUCTION}

Over $50 \%$ of metastatic melanomas harbor the
BRAF(V600E) point mutation (T1799A)[1, 2]. Mutant $\mathrm{BRAF}(\mathrm{V} 600 \mathrm{E})$ represents a constitutively active protein serine kinase that leads to the sustained activation of the $\mathrm{BRAF} \rightarrow \mathrm{MEK} 1 / 2 \rightarrow \mathrm{ERK} 1 / 2 \mathrm{MAP}$ kinase pathway[3, 
4]. This pathway plays a critical role in the regulation of gene expression as well as cell proliferation and survival, which are all involved in the initiation and progression of melanoma[5, 6]. Clinical trials have demonstrated that the BRAF inhibitor (BRAF-I), PLX4032 (vemurafenib), and other inhibitors in its class (GSK2118436 or dabrafenib) can induce tumor regression in more than $50 \%$ of the patients with metastatic melanoma harboring the $\mathrm{BRAF}(\mathrm{V} 600 \mathrm{E})$ mutation and improve both progressionfree and overall survival $[7,8]$. Although the clinical activity of BRAF-I therapy is a major breakthrough in the treatment of metastatic melanoma, the median time to disease progression is less than 7 months due to acquired resistance[8]. Furthermore complete responses to vemurafenib are only observed in $5 \%$ of patients, as a consequence of intrinsic BRAF-I resistance[7, 9].

The multiple mechanisms underlying melanoma BRAF-I resistance, most of which have been validated by clinical evidence[10-14], can be classified into two groups. One includes ERK signaling reactivation, caused by point mutations in MEK1[10, 15], amplification of mutant BRAF(V600E)[16], elevated CRAF activity[17], activating NRAS mutations [11], increased levels of COT/Tp12[12] and/or aberrantly spliced BRAF(V600E) [13]. The other one includes activation of alternative protumorigenic pathways such as the PI3K/AKT pathway that can be caused by phosphatase and tensin homolog (PTEN) loss [18] or by an increase in signaling driven by receptor tyrosine kinases (RTK). The latter include the platelet-derived growth factor (PDGFR) $\beta[11,19]$ and the insulin-like growth factor receptor (IGF1R) [14]. To the best of our knowledge, PDGFR $\alpha$, a RTK which markedly differs in its functional properties from its family member PDGFR $\beta$, has not been implicated in BRAF-I resistance of BRAF(V600E) melanoma.

In this study we provide for the first time both in vitro and in vivo evidence that PDGFR $\alpha$ up-regulation causes BRAF-I resistance of BRAF(V600E) melanoma cells. Furthermore, we show that PDGFR $\alpha$ up-regulation is mediated by activation of the Sonic Hedgehog Homolog (Shh) pathway which is induced by BRAF-I treatment. Lastly, we describe combinatorial strategies which can be easily translated to a clinical setting to counteract the $\mathrm{Shh} /$ PDGFR $\alpha$ mediated BRAF-I resistance of BRAF(V600E) melanoma cells.

\section{RESULTS}

\section{ERK reactivation, AKT activation and PDGFR $\alpha$ up-regulation in melanoma cell lines with acquired BRAF-I resistance}

The parental Colo38 and M21 cell lines were compared in their sensitivity to the anti-proliferative activity of the BRAF-I vemurafenib to the autologous cell lines Colo38R, and M21R and the allogeneic cell line TPF-10-741. Parental Colo38 and M21 cells were highly sensitive to the anti-proliferative activity of vemurafenib at the concentrations ranging between $250 \mathrm{nM}$ and 2000 nM. In contrast, Colo38R and M21R cells showed a markedly lower sensitivity to the growth inhibitory effects of vemurafenib (Supplementary Figure 1). TPF-10-741 cells displayed an intermediate sensitivity to vemurafenib. This acquired resistance model was used to investigate the molecular mechanisms underlying disease progression after an initial response to vemurafenib. Since acquired BRAF-I resistance can be mediated by reactivation of the MAPK pathway or by activation of alternative pathways like PI3K/AKT, we evaluated signaling through these pathways in both parental and resistant cell lines (Figure 1A). Following a 1 and a 24 hour (h) incubation at $37^{\circ} \mathrm{C}$ with vemurafenib, phospho- (p)-ERK levels were markedly reduced in both Colo38 and M21 cells, but were changed to a limited extent or not at all in Colo38R and M21R cells. The latter cells also displayed much higher levels of p-ERK as compared to the parental cells under basal conditions $(P<0.05)$. As described by Lito et al. in other BRAF(V600E) melanoma cell lines [20], p-ERK levels rebounded after a $24 \mathrm{~h}$ incubation at $37^{\circ} \mathrm{C}$ with vemurafenib in both Colo38 and M21 cells. However no changes were detected in Colo38R and M21R cells. Similarly to the resistant cells, in partially resistant TPF-10-741 cells p-ERK levels were changed to a limited extent rebounding just at $24 \mathrm{~h}$ incubation with vemurafenib. p-AKT levels were increased in Colo38R and M21R cells compared to Colo38 and M21 cells $(P<0.05)$. p-AKT levels were also increased in Colo38, M21 and TPF-10-741 cells after treatment with vemurafenib $(P<0.05)$.

To investigate the mechanisms underlying the melanoma cell resistance to BRAF-I, the expression and activation of the RAF/MEK/ERK and PI3K/AKT pathway components were analyzed in the cell lines both under basal conditions and after treatment with vemurafenib. CRAF and MEK were reactivated in Colo38R, M21R, and TPF-10-741 cells. PI3K was activated in Colo38, M21 and TPF-10-741 cells after treatment with vemurafenib (Figure 1B), but its levels were not affected in Colo38R and M21R cells. PTEN was not detected in TPF-10-741 cells, but was expressed in the other cell lines (Figure 1B). Therefore the resistance of melanoma cell lines to BRAF-I was associated with the simultaneous reactivation of the MAPK pathway and with the activation of the PI3K/ AKT pathway. The latter might be caused by an upstream activator of MAPK and PI3K/AKT pathways. To exclude the presence of NRAS mutations as well as the presence of additional alterations in BRAF gene, a RT-PCR was performed in parental and resistant cell lines. No changes were detected in NRAS sequence and the BRAF(V600E) mutation was present in both parental and resistant cell 
lines (Supplementary Figure S2). Since BRAF-I resistance through reactivation of MAPK pathway and activation of PI3K/AKT pathway can be mediated by RTK upregulation [11], we investigated the potential role of RTK PDGFR $\alpha$, PDGFR $\beta$ and VEGFR2 in BRAF-I resistance. As shown in Figure 1C, vemurafenib enhanced PDGFR $\alpha$ expression and activation in Colo38 and M21 cells $(P<0.05)$. Furthermore PDGFR $\alpha$ levels were higher in Colo38R and M21R cells as compared to the parental cells $(P<0.05)$. PDGFR $\alpha$ was expressed and activated in TPF10-741 cells both under basal conditions and following treatment with vemurafenib. PDGFR $\beta$ was up-regulated on TPF-10-741 cells after treatment with vemurafenib, but was not detectable in the other cell lines both under basal conditions and following treatment with vemurafenib. Lastly, VEGFR2 expression was not detected in any cell lines before or after treatment with vemurafenib.

\section{Induction by PDGFRa up-regulation of melanoma cell line resistance to BRAF-I}

To test whether PDGFR $\alpha$ up-regulation caused BRAF-I resistance in Colo38R, M21R and TPF-10-741 cells, PDGFR $\alpha$ was knocked down in the three cell lines using 5 PDGFR $\alpha$-specific short hairpin RNA (shRNAs). As shown in Figure 2A, lentiviral transduction of M21R
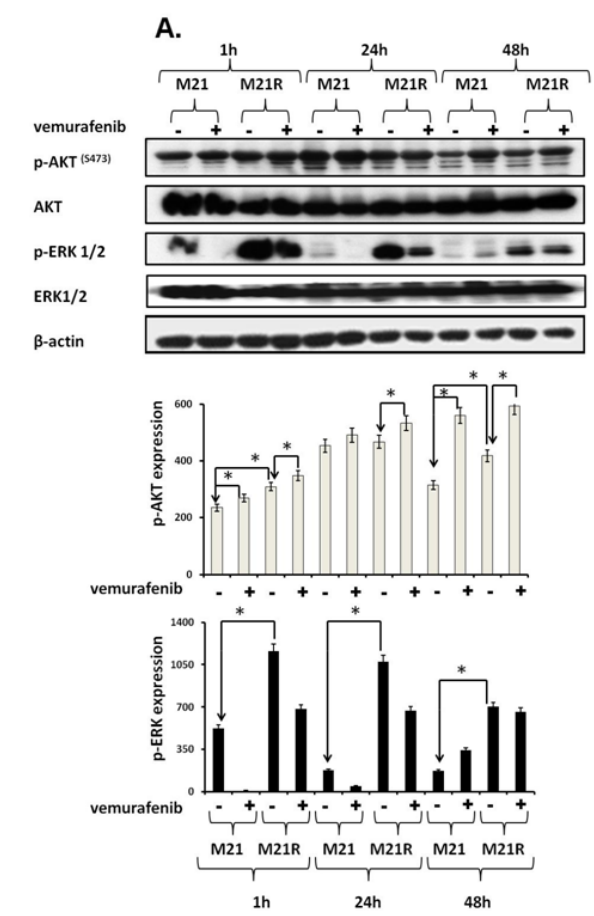

B.

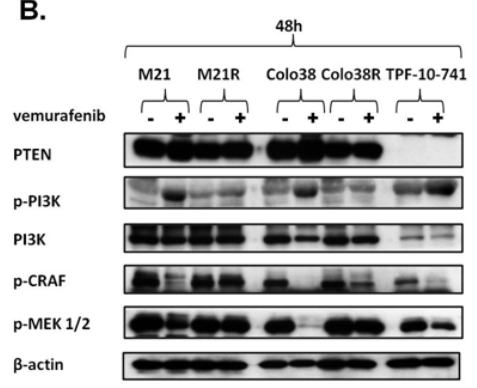

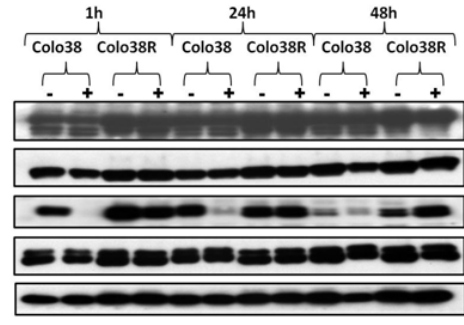
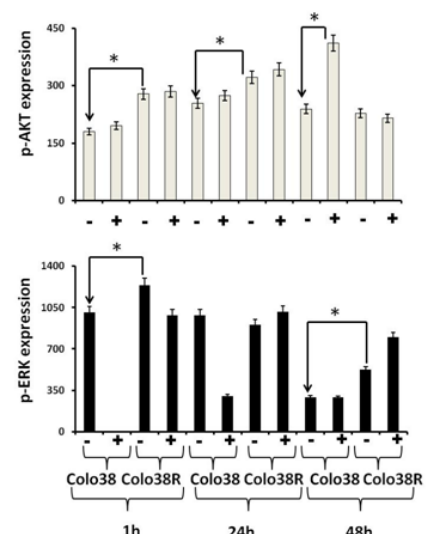

C.

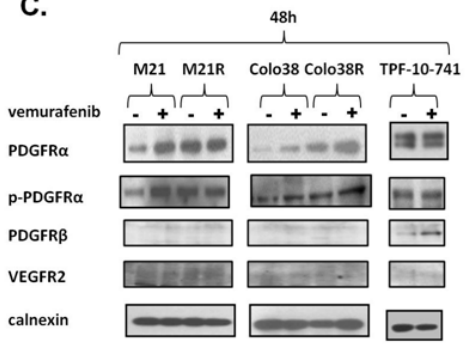

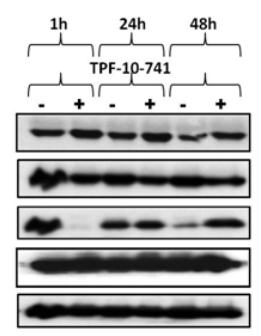
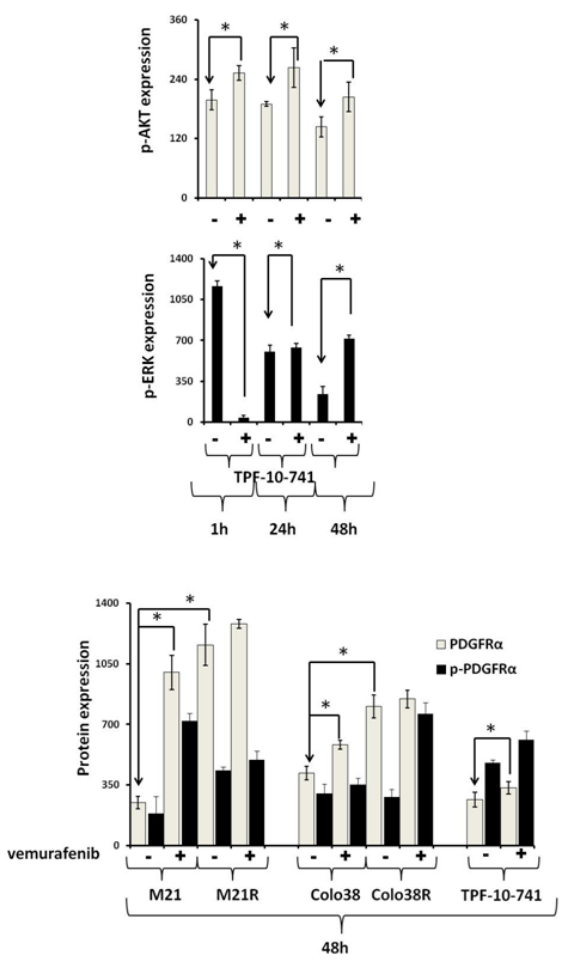

Figure 1: Association of BRAF-I resistance with MAPK reactivation, PI3K/AKT activation and PDGFR $\alpha$ up-regulation in BRAF(V600E) melanoma cell lines.Cells were treated with the BRAF-I vemurafenib (1 $\boldsymbol{\mu M})$. A. Following an up to $48 \mathrm{~h}$ incubation at $37^{\circ} \mathrm{C}$ cells were harvested and lysed. Cell lysates were analyzed by western blot with the indicated mAbs. $\beta$-actin was used as a loading control. A representative result is shown (upper panel). The levels of p-ERK and p-AKT normalized to $\beta$-actin are plotted and expressed as mean $\pm \mathrm{SD}$ of the results obtained in three independent experiments (lower panel). The asterisk $(*)$ indicates $P<0.05$. B. Following a $48 \mathrm{~h}$ incubation at $37^{\circ} \mathrm{C}$ cells were harvested and lysed. Cell lysates were analyzed by western blot with the indicated mAbs. $\beta$-actin was used as a loading control. C. Following a $48 \mathrm{~h}$ incubation at $37^{\circ} \mathrm{C}$ cells were harvested and lysed. Cell lysates were analyzed by western blot with the indicated mAbs. Calnexin was used as a loading control. A representative result is shown (left panel). The levels of PDGFR $\alpha$ and p-PDGFR $\alpha$ normalized to calnexin are plotted and expressed as mean \pm SD of the results obtained in three independent experiments (right panel). The asterisk (*) indicates $P<0.05$. 
cells with a PDGFR $\alpha$-specific $\operatorname{shRNA(\# 4)~construct~}$ knocked down p-PDGFR $\alpha$ and PDGFR $\alpha$ expression $(p<0.05)$. PDGFR $\alpha$ down-regulation was associated with a minimal decrease in p-ERK and p-AKT levels $(P<0.05)$ as compared to untreated cells. However, this effect was markedly enhanced when the cells transduced with PDGFR $\alpha$-specific shRNA(\#4) were treated with vemurafenib $(P<0.05)$ which slightly decreased p-ERK levels and increased p-AKT expression. Additionally, as shown in Figure 2B, M21R and TPF-10-741 cells transduced with the PDGFR $\alpha$-specific $\operatorname{shRNA(\# 4)}$ displayed a significantly increased sensitivity to the antiproliferative effect of vemurafenib when compared to the autologous cells transduced with a GFP-shRNA $(P<0.01)$ (IC50 $\leq 20$ times).

\section{Association of PDGFRa up-regulation in melanoma patient derived biopsies with BRAF-I resistance}

To assess the potential clinical significance of our in vitro results, we tested PDGFR $\alpha$ expression in biopsies obtained from 9 melanoma patients treated with BRAF-I or with the novel combination of BRAF-I and MEK inhibitor (MEK-I) [21]. Tumor biopsies were performed pre-treatment (day 0), at 10-14 days on treatment, and/or at the time of disease progression. Immunohistochemical (IHC) staining demonstrated PDGFR $\alpha$ up-regulation in 5 out of 9 patients following treatment with BRAF-I +/MEK-I (Figure 3A). In 3 of the 5 patients a significant increase in PDGFR $\alpha$ expression $(>1+)$ was observed after treatment. Patients with a significant $(>1+)$ increase in PDGFR $\alpha$ expression after treatment with BRAF-I +/MEK-I had less tumor regression (Figure $3 \mathrm{~B}$ ) and shorter time to disease progression (Figure $3 \mathrm{C})(P=0.07)$ when compared to patients who had no change or a small change in PDGFR $\alpha$ expression $(\leq 1+)$.

\section{Increase by PDGFR $\alpha$-I of the anti-tumor activity of BRAF-I in BRAF-I sensitive and resistant melanoma cell lines}

To investigate whether the anti-tumor activity of BRAF-I could be enhanced by PDGFR $\alpha$ inhibition,
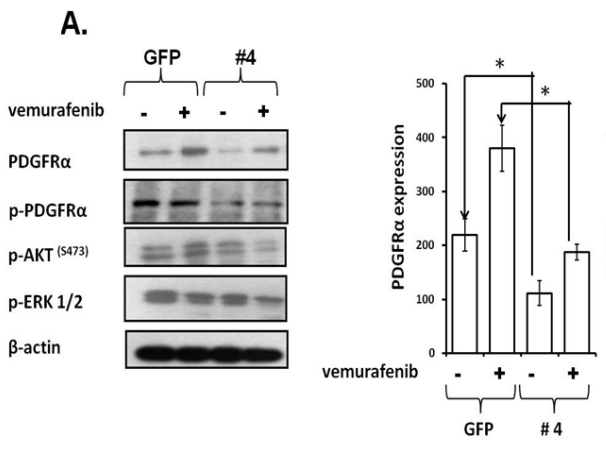

B.

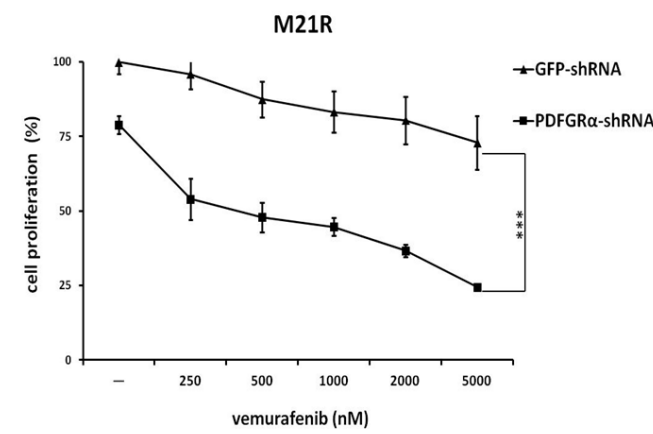

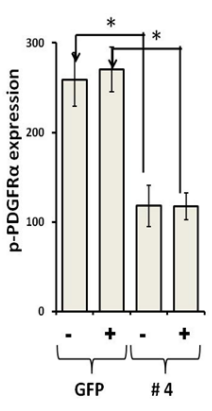
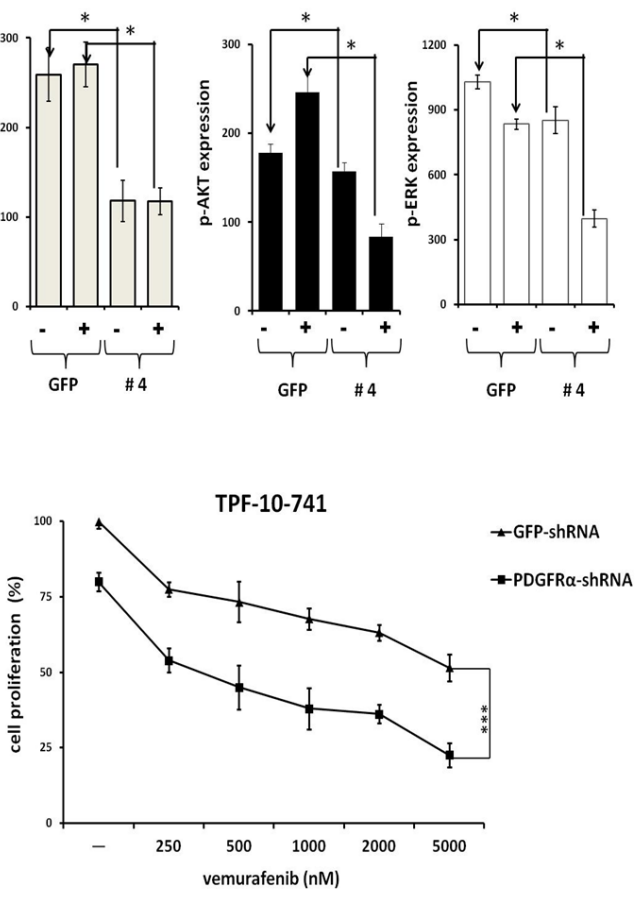

Figure 2: Restoration by PDGFRa down-regulation of BRAF-I sensitivity of BRAF(V600E) melanoma cell lines with acquired BRAF-I resistance. A. M21R transduced with PDGFR $\alpha$-specific shRNA (\#4) or GFP-shRNA lentiviral particles were treated with the BRAF-I vemurafenib $(1 \mu \mathrm{M})$. Following a 3 day incubation at $37^{\circ} \mathrm{C}$ cells were harvested and lysed. Cell lysates were analyzed by western blot with the indicated mAbs. $\beta$-actin was used as a loading control. A representative result is shown (left panel). The levels of PDGFR $\alpha, p$ - PDGFR $\alpha$, p-ERK and p-AKT normalized to $\beta$-actin are plotted and expressed as mean \pm SD of the results obtained in three independent experiments (right panel). The asterisk (*) indicates $P<0.05$. B. PDGFR $\alpha$-specific shRNA (\#4) transduced M21R and TPF10-741 cells were treated with the indicated vemurafenib concentrations. GFP-shRNA transduced M21R and TPF-10-741 cells were used as controls. Cell proliferation was determined by MTT assay following a 3 day incubation at $37^{\circ} \mathrm{C}$. Percentage of cell proliferation was calculated as the ratio of treated cells to untreated GFP-shRNA transduced cells. Data are expressed as mean \pm SD of the results obtained in three independent experiments. The asterisks $(* * *)$ indicate $P<0.01$. 
Colo38, Colo38R, M21, M21R and TPF-10-741 cells were treated with vemurafenib in combination with the PDGFR $\alpha$ inhibitor (PDGFR $\alpha-\mathrm{I})$ sunitinib [22], imatinib [23] or crenolanib [24]. A titration experiment established the dose of the PDGFR $\alpha$-I to be combined with vemurafenib in the 5 cell lines. The IC50 doses of sunitinib, imatinib and crenolanib were found to be 2,15 and $1.5 \mu \mathrm{M}$, respectively (Supplementary Figure 3 ). In line with the data in the literature [25-35], the doses of 1.5 and $3 \mu \mathrm{M}$ for sunitinib, 10 and $20 \mu \mathrm{M}$ for imatinib and 1 and $2 \mu \mathrm{M}$ for crenolanib, were tested in combination with vemurafenib for their anti-proliferative effect and induction of apoptosis. As shown in Figure 4A and Supplementary Figure 4, vemurafenib and PDGFR $\alpha-\mathrm{I}$ combination inhibited the proliferation of Colo38 and M21 cells to a significantly greater extent $(P<0.05)$ than each agent alone. Furthermore, as observed with cells transduced with the PDGFR $\alpha$-specific shRNA, PDGFR $\alpha$-I synergized $(P<0.05)$ with vemurafenib in the inhibition of Colo38R, M21R and TPF-10-741 cell growth. Lastly, vemurafenib and PDGFR $\alpha$-I (crenolanib or sunitinib) combination (Figure 4B and Supplementary

A.

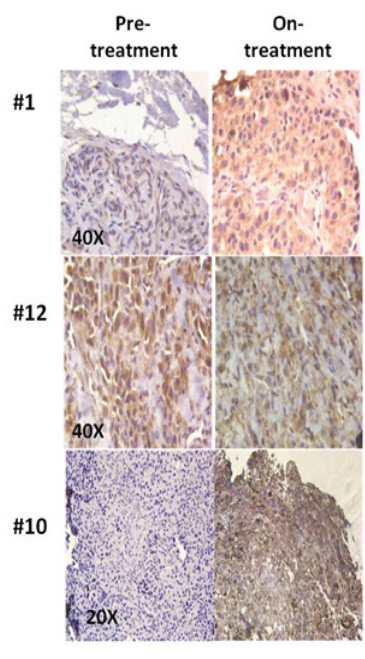

B.

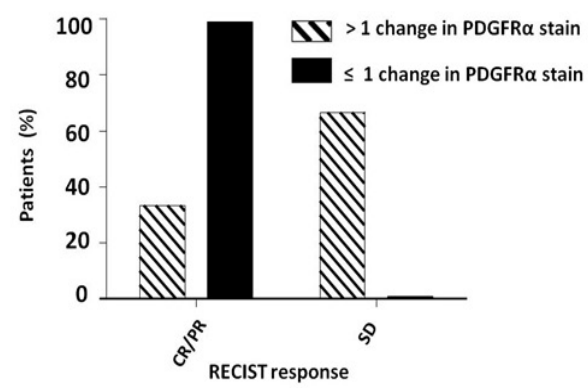

C.

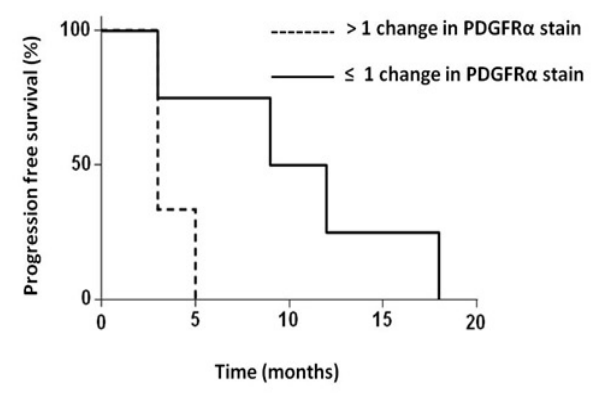

Figure 3: PDGFRa expression in melanoma metastases obtained from patients who acquired BRAF-I resistance. Melanoma tumors were biopsied before treatment (day 0), at 10-14 days on treatment, and/or at the time of disease progression following treatment with BRAF-I or with BRAF-I and MEK-I. Tumor sections were stained with H\&E and PDGFR $\alpha$-specific rabbit antibody. Scores were recorded semiquantitatively as $1+, 2+, 3+$ and $4+$, when $1-25 \%, 26-50 \%, 51-75 \%$ and $>75 \%$ of melanoma cells were stained, respectively. Patients were divided in two groups based on change of PDGFR $\alpha$ expression, as measured by IHC staining of melanoma biopsies: those whose PDGFR $\alpha$ staining score had no or 1 point increase after treatment $(\leq 1+)$ and those whose PDGFR $\alpha$ staining score increased 2 or more points after treatment $(>1+)$. A. Representative IHC staining of PDGFR $\alpha$ expression in melanoma patients before treatment, at 10-14 days on treatment and at the time of disease progression in 5 out of 9 tumor biopsies. Tissue from a human GIST and its lymphocyte infiltrate were used as a positive and a negative control, respectively, for PDGFR $\alpha$ expression. The magnification used is indicated in the panels of the figure. B. Two groups of patients were graphed based upon RECIST (complete response (CR), partial response (PR) and stable disease (SD)) and compared as a percent of the total population of the PDGFR $\alpha$ stain score group. C. Two groups of patients were graphed based upon the time to disease progression utilizing Kaplan-Meier method. 
Figure 5) induced apoptosis in a significantly $(P<0.05)$ higher percentage of cells than each agent alone in both BRAF-I sensitive and resistant cell lines. It is worth noting that crenolanib and sunitinib induced apoptosis in both BRAF-I sensitive and resistant cell lines $(P<0.05)$, while vemurafenib had no detectable effect.

\section{Inhibition by BRAF-I and PDGFRa-I of ERK and AKT activation in BRAF-I sensitive and resistant melanoma cell lines}

We next investigated whether the enhanced antiproliferative and pro-apoptotic activity of BRAF-I and
PDGFR $\alpha$-I combination was mediated by an increased inhibition of ERK and AKT activation in BRAF-I sensitive and resistant cells. As shown in Figure 5, p-ERK and p-AKT levels were markedly decreased in both BRAF-I sensitive and resistant melanoma cells after treatment with vemurafenib and PDGFR $\alpha-\mathrm{I}$ combination. Specifically, p-ERK levels were dramatically decreased in Colo38 and M21 cells treated with vemurafenib. In contrast p-ERK levels were minimally decreased in Colo38 and M21 cells treated with PDGFR $\alpha$-I. In addition, p-AKT levels were increased in M21 cells treated with vemurafenib, but were reduced in Colo38 and M21 cells treated with PDGFR $\alpha$-I. However both p-ERK and p-AKT levels

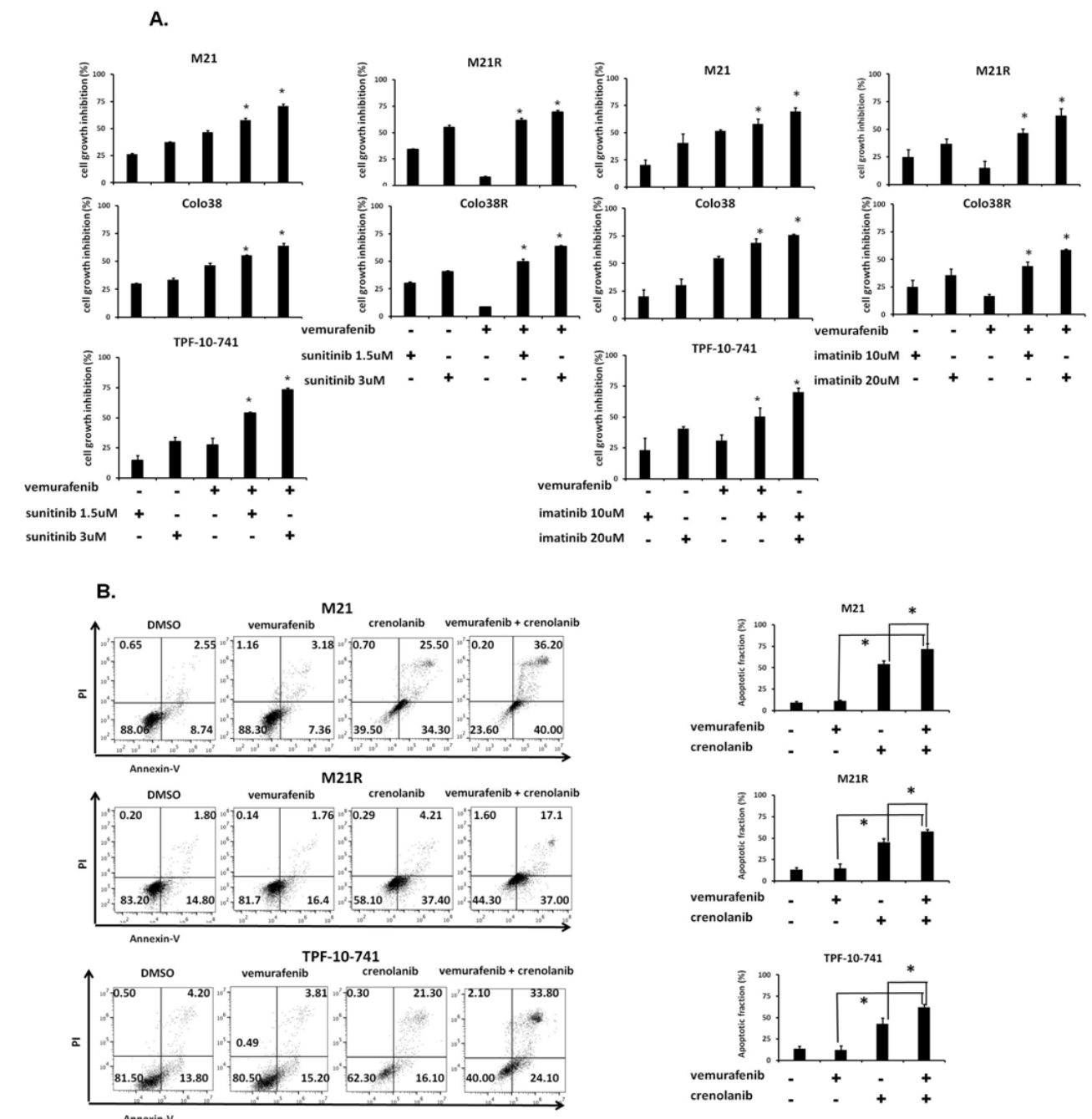

Figure 4: Enhancement by PDGFRa-I of the in vitro anti-proliferative and pro-apoptotic activity of BRAF-I in BRAF-I sensitive and resistant melanoma cell lines harboring BRAF(V600E). A. Cells were treated with the BRAF-I vemurafenib (500 $\mathrm{nM}$ ) and/or the indicated concentration of PDGFR $\alpha$-I sunitinib (left panel) or imatinib (right panel). Cell growth inhibition was determined by MTT assay following a 3 day incubation at $37^{\circ} \mathrm{C}$. Percentage of cell growth inhibition was calculated as ratio of treated to untreated cells for each treatment. Data are expressed as mean \pm SD of the results obtained in three independent experiments. The asterisk $\left({ }^{*}\right)$ indicates $P<0.05$. B. Cells were treated with the BRAF-I vemurafenib $(500 \mathrm{nM})$ and/or the PDGFR $\alpha$-I crenolanib $(1 \mu \mathrm{M})$. Following a 24 $\mathrm{h}$ incubation at $37^{\circ} \mathrm{C}$ cells were harvested and stained with Annexin V and PI. A representative result is shown (left panel). The levels of apoptosis are plotted and expressed as mean fraction of apoptotic cells $\pm \mathrm{SD}$ of the results obtained in three independent experiments (right panel). The asterisk (*) indicates $P<0.05$. 
were markedly inhibited in Colo38 and M21 cells treated with vemurafenib and PDGFR $\alpha$-I combination. On the other hand, p-ERK levels were minimally inhibited by vemurafenib in TPF-10-741 cells as well as in Colo38R and M21R cells when compared with parental cell lines. As observed with cells transduced with the PDGFR $\alpha$ specific shRNA, PDGFR $\alpha$-I decreased p-ERK and p-AKT levels in Colo38R, M21R and TPF-10-741 cells. However, vemurafenib and PDGFR $\alpha-\mathrm{I}$ combination markedly decreased both p-ERK and p-AKT levels to a greater extent than each agent alone in all of the BRAF-I resistant cell lines (Figure 5).

\section{Enhancement by PDGFRa-I of the in vivo anti- tumor activity of BRAF-I in BRAF-I sensitive and resistant BRAF(V600E) melanoma cell lines}

To assess the in vivo relevance of our in vitro results, vemurafenib and sunitinib combination was tested for its ability to inhibit the growth of M21 and M21R cells in severe combined immunodeficiency (SCID) mice. The oral administration of the drugs, either in combination or as individual agents, caused no overt side effects (data not shown). In the mice grafted with M21 cells (Figure 6A) vemurafenib (12.5 mg/kg twice per day) and sunitinib $(20 \mathrm{mg} / \mathrm{Kg} /$ day) combination inhibited tumor growth to a significantly $(P<0.001)$ greater extent than each single agent. Both vemurafenib and sunitinib inhibited tumor growth as single agents to a similar extent $(P<0.001)$. It is noteworthy that sunitinib was administered at a lower dose $(20 \mathrm{mg} / \mathrm{Kg} /$ day $)$ as compared to the dose used by other investigators (40 mg/Kg/day)[26, 27, 36]. Nevertheless, sunitinib was effective in enhancing the anti-tumor activity of vemurafenib. Analysis of the tumor cell lysates removed from treated and untreated mice (Figure 6B) demonstrated that vemurafenib and sunitinib combination markedly reduced both $\mathrm{p}$-ERK and p-AKT levels. Sunitinib by itself slightly decreased p-ERK and p-AKT levels, while vemurafenib decreased p-ERK levels but increased p-AKT levels. IHC analysis of the primary tumors demonstrated a marked reduction in the number of mitoses in tumors from mice treated with vemurafenib and sunitinib combination (Figure 6C) when compared to tumors from mice treated with each single agent $(P<0.001)$ or from untreated mice $(P<0.001)$. Both vemurafenib and sunitinib reduced significantly the number of mitoses in tumors as compared to untreated mice $(P<0.001)$. The number of apoptotic cells (Figure 6D) in tumors from mice treated with vemurafenib and sunitinib combination was significantly higher than in tumors from untreated mice or from mice treated with vemurafenib or sunitinib individually $(P<0.001)$. Sunitinib, but not vemurafenib induced apoptosis in a significantly higher number of cells in tumors when compared to untreated mice $(P<0.001)$.

In the mice grafted with M21R cells (Figure 6E),

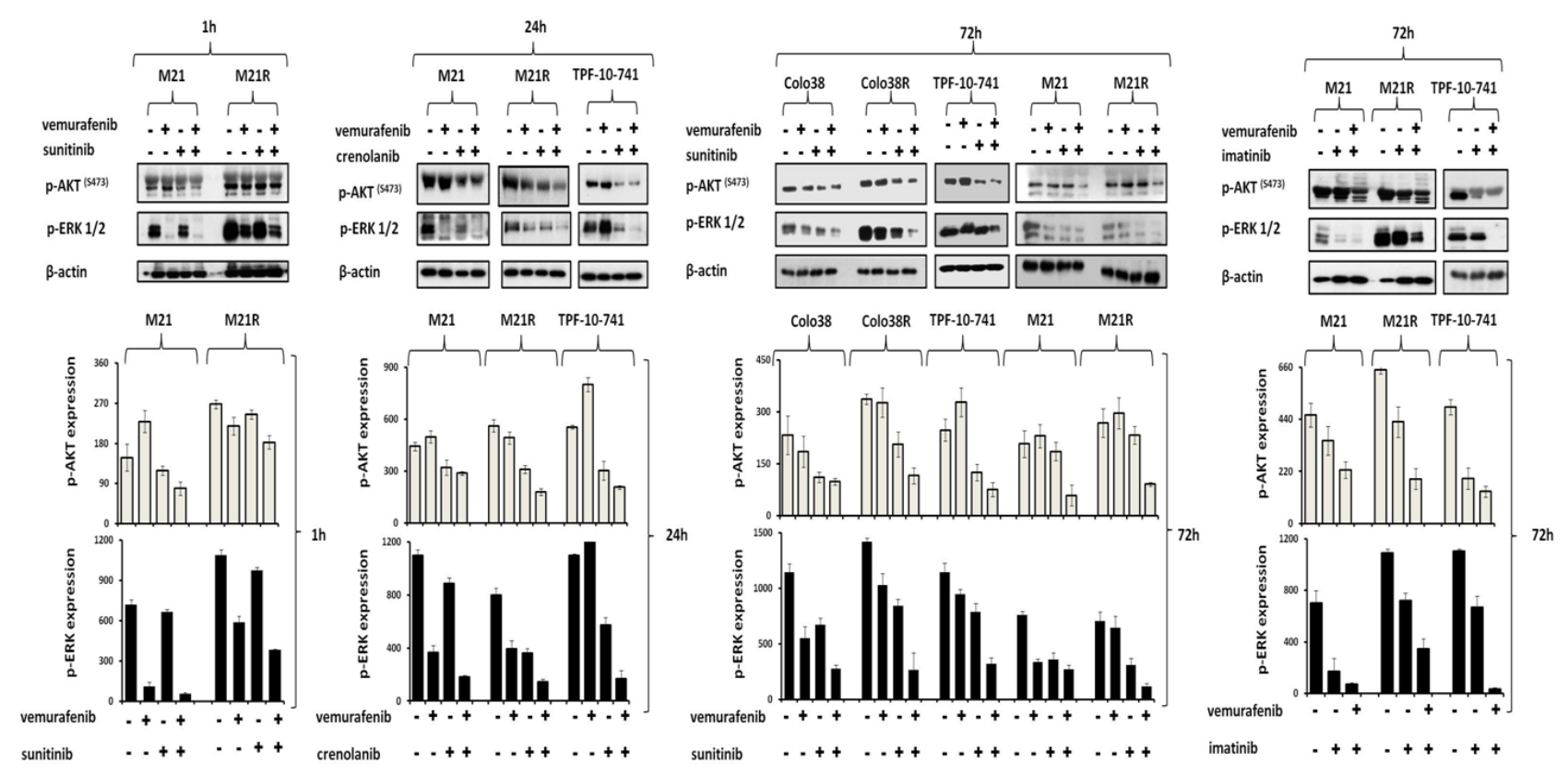

Figure 5: Enhancement by PDGFR $\alpha-I$ of the signaling pathway inhibition by BRAF-I in BRAF-I sensitive and resistant melanoma cell lines harboring BRAF(V600E). Cells were treated with the BRAF-I vemurafenib (1 $\mu \mathrm{M})$ and/or the PDGFR $\alpha-I$ sunitinib $(1.5 \mu \mathrm{M})$ and/or imatinib $(10 \mu \mathrm{M})$ and/or crenolanib $(1 \mathrm{uM})$. Following an up to $72 \mathrm{~h}$ incubation at $37^{\circ} \mathrm{C}$, cells were harvested and lysed. Cell lysates were analyzed by western blot with the indicated mAbs. $\beta$-actin was used as a loading control. Representative results are shown (upper panel). The levels of p-ERK and p-AKT normalized to $\beta$-actin are plotted and expressed as mean \pm SD of the results obtained in two independent experiments (lower panel). 
as expected, vemurafenib did not inhibit tumor growth as compared to untreated mice. In contrast, sunitinib significantly inhibited tumor growth as compared to untreated mice $(P<0.001)$ or to mice treated with vemurafenib $(P<0.001)$. This effect was significantly enhanced when sunitinib was combined with vemurafenib $(P<0.001)$. Analysis of the tumor lysates (Figure 6F) demonstrated that, while vemurafenib had no detectable effect on p-ERK and p-AKT levels, sunitinib inhibited both of them. This effect was more marked in tumors from mice treated with vemurafenib and sunitinib combination. IHC analysis of the primary tumors showed a significantly lower number of mitoses in tumors from mice treated with sunitinib (Figure 6G) when compared to that in tumors from vemurafenib treated or untreated mice $(P<0.001)$. In addition, sunitinib strongly increased the number of apoptotic cells in tumors as compared to vemurafenib or untreated mice $(P<0.001)$ (Figure $6 \mathrm{H})$. However vemurafenib and sunitinib combination decreased the number of mitotic cells and increased that of apoptotic
A.

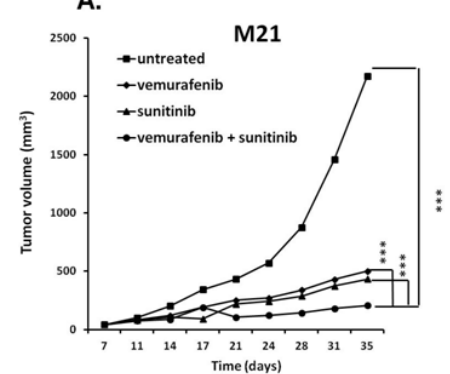

c.

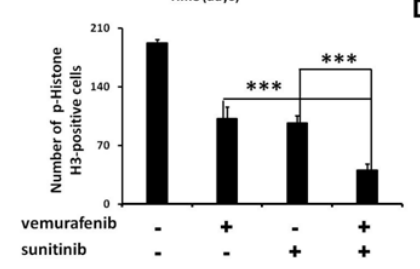

E.

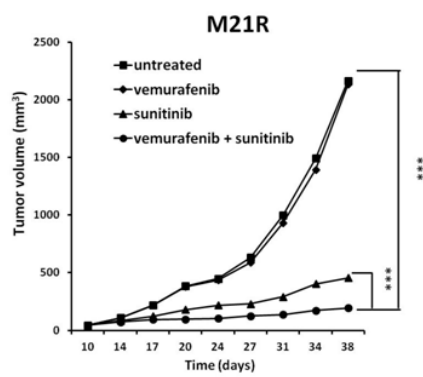

G.

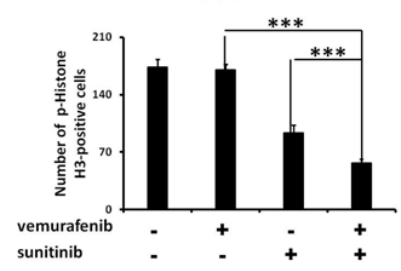

B.

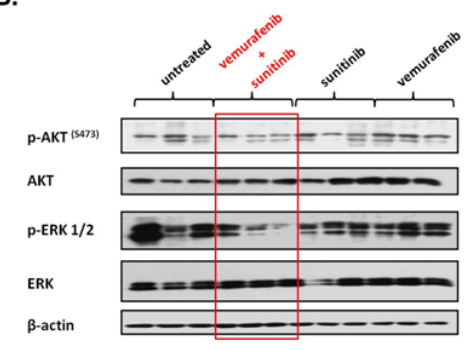

D.

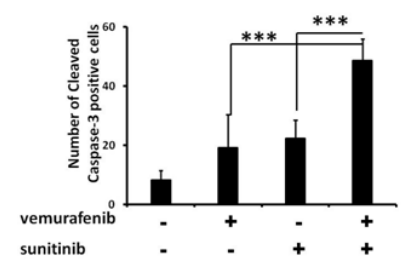

F.

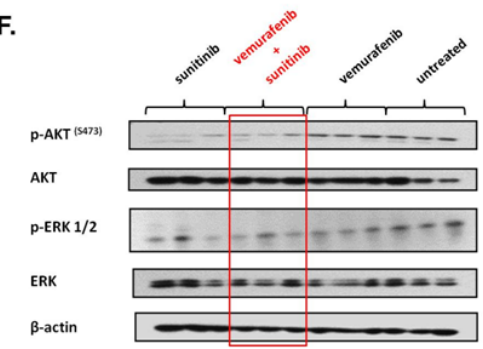

H.

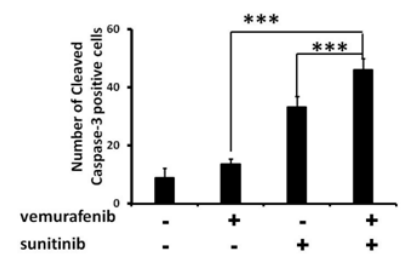

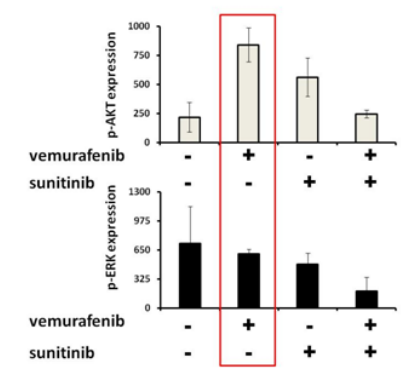

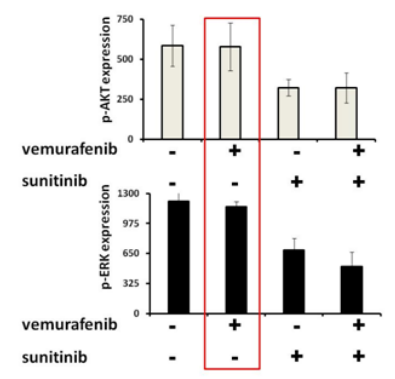

Figure 6: Enhancement by PDGFR $\alpha$-I of the anti-tumor activity of BRAF-I in human BRAF(V600E) melanoma cells grafted in immunodeficient mice. A, E. M21 and M21R cells were each implanted subcutaneously in 20 SCID mice. When tumors became palpable, mice were randomly divided into 4 groups ( 5 mice/group). One group was treated with the BRAF-I vemurafenib $(12.5 \mathrm{mg} / \mathrm{kg} /$ twice per day), one with the PDGFR $\alpha$-I sunitinib $(20 \mathrm{mg} / \mathrm{kg} / \mathrm{day})$ and one with vemurafenib $(12.5 \mathrm{mg} / \mathrm{kg} / \mathrm{twice} \mathrm{per} \mathrm{day)} \mathrm{in}$ combination with sunitinib $(20 \mathrm{mg} / \mathrm{kg} / \mathrm{day})$. One group of mice was left untreated as a reference for the natural course of the disease. Efficacy data are plotted as mean tumor volume $\left(\right.$ in $\left.\mathrm{mm}^{3}\right) \pm \mathrm{SD}$. The asterisks $(* * *)$ indicate $P<0.001$. B, F. Tumors harvested from untreated and treated mice were lysed and analyzed for expression and activation of the indicated signaling pathway components. $\beta$-actin was used as a loading control. Three representative tumor cell lysates for each group of mice are shown (left panel). The levels of p-ERK and $\mathrm{p}$-AKT normalized to $\beta$-actin are plotted and expressed as mean \pm SD of the results obtained with the five tumor cell lysates in each group (right panel). C, G. Tissue sections obtained from the harvested tumors were analyzed for the content of mitotic cells by staining with p-Histone H3 (Ser10) protein-specific antibody. Mitotic tumor cells were quantified by counting 5 randomly selected high-power fields per section (magnification $\times 200$ ). D, H. Tissue sections obtained from the harvested tumors were analyzed for the content of apoptotic cells by staining with Cleaved Caspase-3 (Asp175)-specific antibody. Apoptotic tumor cells were quantified by counting 5 randomly selected highpower fields per section (magnification $\times 200$ ). Data are presented as means \pm SD. The asterisks $(* * *)$ indicate $P<0.001$. 
cells to a significantly $(P<0.001)$ greater extent than sunitinib alone.

To prove that the results obtained with sunitinib did not reflect potential off target effects of sunitinb we tested the therapeutic efficacy of the other PDGFR $\alpha$-I imatinib in combination with a higher dose of vemurafenib (25 mg/kg twice per day). Imatinib was administered at a dose $(100 \mathrm{mg} / \mathrm{kg} /$ day $)$ which has been used by other investigators [31, 32]. As expected vemurafenib and imatinib combination inhibited tumor growth of M21 cells to a significantly $(P<0.001)$ greater extent than each single agent, although imatinib displayed lower anti-tumor activity than sunitinib and vemurafenib had a higher antitumor effect. (Supplementary Figure 6).

\section{Role of Shh pathway activation in PDGFRa up-regulation mediated BRAF-I resistance of melanoma cells}

The previously described role of the Shh pathway and Glil activation[37-40] in PDGFR $\alpha$ up-regulation associated with the MAPK and PI3K/AKT pathway activation prompted us to investigate whether Gli1 activation is involved in PDGFR $\alpha$ up-regulation in BRAF(V600E) melanoma cells. As shown in Figure 7A, vemurafenib enhanced Gli1 expression in Colo38, Colo38R, M21, M21R, and TPF-10-741 cells as compared to untreated cells $(P<0.05)$. Similarly to PDGFR $\alpha$ inhibition, inhibition of Gli1 activation by the novel clinically available Shh inhibitor (Shh-I) LDE225[41] restored $(P<0.05)$ and increased $(P<0.05)$ melanoma

A.

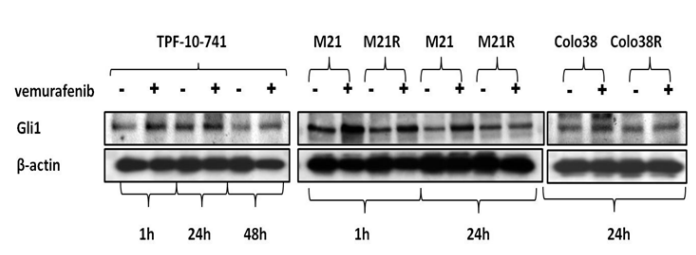

B.

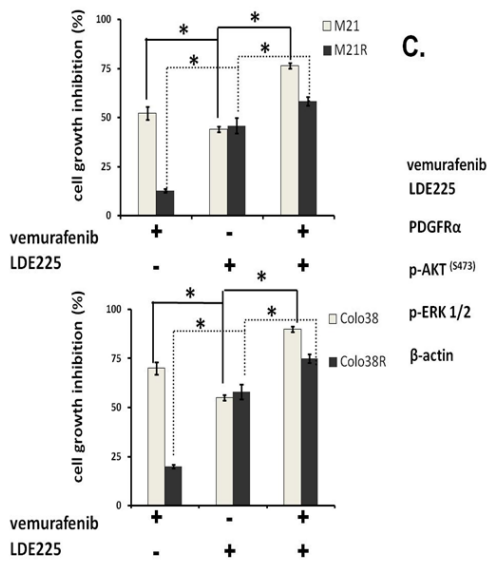

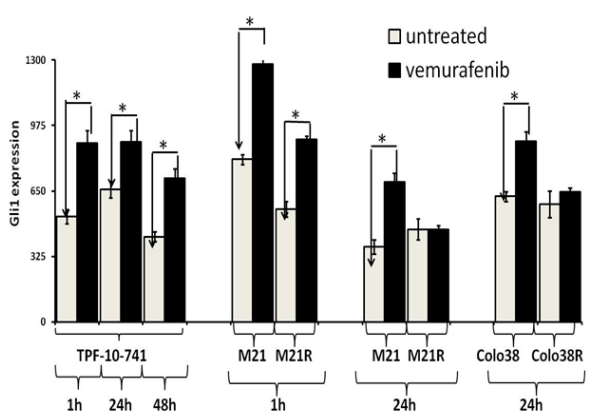

D.
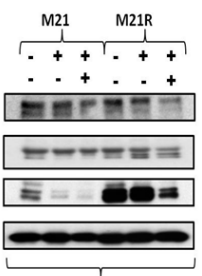

$48 \mathrm{n}$

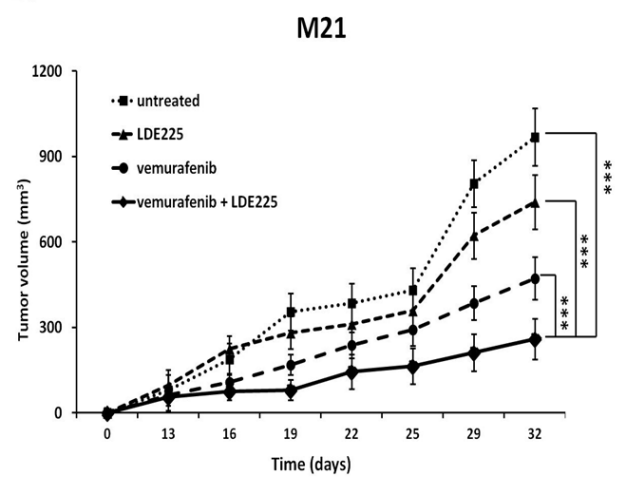

Figure 7: Association of Gli1 activation with PDGFR $\alpha$ up-regulation mediating BRAF-I resistance in melanoma cell lines harboring BRAF(V600E). A. Cells were treated with the BRAF-I vemurafenib $(1 \mu \mathrm{M})$. Following an up to $72 \mathrm{~h}$ incubation at $37^{\circ} \mathrm{C}$ cells were harvested and lysed. Cell lysates were analyzed by western blot with the indicated mAbs. $\beta$-actin was used as a loading control. A representative result is shown (left panel). The level of Glil normalized to $\beta$-actin is plotted and expressed as mean \pm SD of the results obtained in three independent experiments (right panel). The asterisk $\left(^{*}\right)$ indicates $P<0.05$. B. Cells were treated with vemurafenib $(1 \mathrm{uM})$ and/or the Shh-I LDE225 $(10 \mathrm{uM})$. Cell growth inhibition was determined by MTT assay following a 3 day incubation at $37^{\circ} \mathrm{C}$. Percentage of cell growth inhibition was calculated as the ratio of treated to untreated cells. Data are expressed as the mean \pm SD of the results obtained in three independent experiments. The asterisk (*) indicates $P<0.05$. C. M21 and M21R cells were treated with vemurafenib $(1 \mu \mathrm{M})$ and/or LDE225 $(10 \mathrm{uM})$. Following a $48 \mathrm{~h}$ incubation at $37^{\circ} \mathrm{C}$ cells were harvested and lysed. Cell lysates were analyzed by western blot with the indicated mAbs. $\beta$-actin was used as a loading control. The data shown are representative of the results obtained in two independent experiments. D. M21 cells were implanted subcutaneously in 20 SCID mice. When tumors became palpable, mice were randomly divided into 4 groups (5 mice/group). One group was treated with the BRAF-I vemurafenib (12.5 mg/ $\mathrm{kg} / \mathrm{twice}$ per day), one with the Shh-I LDE225 (40 mg/kg/day) and one with vemurafenib $(12.5 \mathrm{mg} / \mathrm{kg} / \mathrm{twice}$ per day) in combination with LDE225 (40 mg/kg/day). One group of mice was left untreated as a reference for the natural course of the disease. Efficacy data are plotted as mean tumor volume $\left(\right.$ in $\left.\mathrm{mm}^{3}\right) \pm \mathrm{SD}$. The asterisks $(* * *)$ indicate $P<0.001$. 
cells' sensitivity to BRAF-I (Figure 7B). Furthermore, LDE225 in combination with vemurafenib downregulated PDGFR $\alpha$ expression and inhibited ERK and AKT activation in the BRAF-I sensitive and resistant melanoma cells (Figure 7C). Lastly LDE225 (40 mg/ $\mathrm{Kg}$ /day) enhanced $(\mathrm{p}<0.001)$ the ability of vemurafenib to inhibit the growth of M21 cells in SCID mice (Figure 7D). These results validated the association between Gli1 activation and PDGFR $\alpha$ up-regulation mediating BRAF-I resistance.

\section{DISCUSSION}

PDGFR $\alpha$ is overexpressed in sarcoma and glioma. It is involved in tumor growth, metastasis and neo angiogenesis, as well as in the development of resistance to cytotoxic therapy [42]. These functional properties of PDGFR $\alpha$ are likely to reflect its ability to engage signaling pathways, such as RAS/RAF/MEK/ERK and $\mathrm{PI} 3 \mathrm{~K} / \mathrm{AKT}$ which play a role in tumor cell proliferation and aggressive phenotype. The present study demonstrates that human melanoma cells express PDGFR $\alpha$ both in vitro and in vivo. PDGFR $\alpha$ up-regulation in human melanoma cells harboring the BRAF(V600E) mutation is shown for the first time to be associated with the loss of their sensitivity to the anti-proliferative and pro-apoptotic activity of the BRAF-I vemurafenib both in vitro and in vivo. The association between PDGFR $\alpha$ up-regulation and vemurafenib resistance reflects a cause-effect relationship. Vemurafenib resistance is overcome in melanoma cells which down-regulate PDGFR $\alpha$ expression following transduction with a PDGFR $\alpha$-specific shRNA. An association between the PDGFR $\alpha$ and BRAF(V600E) mutation is also observed in wild type PDGFR $\alpha$ gastrointestinal stromal tumors (GISTs) which acquire the BRAF(V600E) mutation when they develop resistance to PDGFR $\alpha$-I imatinib [43-46].

Vemurafenib resistance of melanoma cells harboring a BRAF mutation reflects ERK and AKT activation induced by PDGFR $\alpha$ up-regulation, since inhibition of its synthesis by PDGFR $\alpha$-specific shRNA causes a reduction of ERK and AKT activation and restores sensitivity to BRAF-I. A similar effect has been demonstrated for the HGF mediated resistance to BRAF-I [47]. This conclusion is corroborated by the in vitro and in vivo results obtained by inhibiting the function of PDGFR $\alpha$ with the clinically approved tyrosine kinase inhibitors sunitinib, imatinib and crenolanib. Sunitinib is an inhibitor of PDGFR $\alpha$, PDGFR $\beta$ and VEGFR2. Imatinib is an inhibitor of PDGFR $\alpha$, PDGFR $\beta$. Crenolanib is a novel and potent inhibitor of PDGFR $\alpha$ and PDGFR $\beta$. It is worth noting that the BRAF(V600E) melanoma cell lines with a PDGFR $\alpha$ up-regulation mediated BRAF-I resistance did not express PDGFR $\beta$ and VEGFR2. Vemurafenib and PDGFR $\alpha-\mathrm{I}$ combination markedly inhibits in vitro proliferation and induces apoptosis of melanoma cells with a PDGFR $\alpha$ up-regulation mediated BRAF-I resistance. These results are paralleled by our in vivo findings. Vemurafenib and PDGFR $\alpha$-I combination inhibited the growth and induced apoptosis in human melanoma cells with PDGFR $\alpha$ upregulation mediated BRAF-I resistance engrafted in immunodeficient mice. These effects are mediated by the inhibition of the RAF/MEK/ERK and PI3K/AKT signaling pathways. The levels of p-ERK and p-AKT were markedly reduced in melanoma cells with PDGFR $\alpha$ upregulation mediated BRAF-I resistance following in vitro or in vivo treatment with vemurafenib and PDGFR $\alpha-\mathrm{I}$ combination. It is noteworthy that this combination has a significantly greater anti-proliferative and pro-apoptotic effect than either agent alone both in vitro and in vivo also with BRAF-I sensitive human melanoma cells which express PDGFR $\alpha$. Therefore, our results suggest that the combinatorial strategy we have designed may overcome not only the acquired, but also the intrinsic BRAF-I resistance if PDGFR $\alpha$ is expressed. Furthermore they confirm that simultaneous inhibition of both the ERK and AKT pathways is more effective in suppressing tumor cell proliferation and in inducing apoptosis in both BRAF-I sensitive and resistant melanoma cells[14, 48-54].

In agreement with the information in the literature [37-40], we have found that PDGFR $\alpha$ up-regulation associated with MAPK and PI3K/AKT activation is regulated by the Shh pathway and by Gli1 activation. Our data confirm this relationship since treatment with BRAF-I enhances Gli1 expression. The latter results are associated with PDGFR $\alpha$ up-regulation mediated BRAF-I resistance since treatment with the novel clinically approved Shh-I LDE225 down-regulates the expression of PDGFR $\alpha$ by inhibiting Gli1 activation. Furthermore, PDGFR $\alpha$ downregulation by the Shh-I LDE225 in combination with vemurafenib enhances tumor growth inhibition in vitro and in vivo and decreases ERK and AKT activation in both sensitive and resistant cell lines.

PDGFR $\alpha$ is not the only growth factor receptor which plays a role in BRAF-I resistance. IGFR1[14] and PDGFR $\beta[11,19]$ are involved in the acquired BRAF-I resistance of melanoma. BRAF-I resistance induced by IGFR and PDGFR $\beta$, similar to PDGFR $\alpha$, is mediated by ERK and AKT activation. However as reported by others[19] and as found by us (data not shown) the PDGFR $\alpha /$ PDGFR $\beta$ inhibitors sunitinib and imatinib are not able to overcome BRAF-I resistance mediated by PDGFR $\beta$ up-regulation. The latter finding reflects the lack of inhibition of ERK activation in spite of the inhibition of AKT activation since the inhibition of these two downstream components of the RAF/MEK/ ERK and PI3K/AKT signaling pathways by a PDGFR $\beta$ specific shRNA restored sensitivity of melanoma cells to vemurafenib.

The potential clinical relevance of our results is suggested by two lines of evidence. First, PDGFR $\alpha$ expression was up-regulated in 5 out of the 9 matched 
melanoma lesions with a BRAF(V600E) mutation, surgically removed from patients who had developed BRAF-I resistance. Second, the extent of PDGFR $\alpha$ increase in melanoma lesions, as measured by the increase in the percentage of stained melanoma cells, was associated with the clinical course of the disease. Specifically a marked increase in PDGFR $\alpha$ expression was associated with a shorter time to progression and less tumor regression based on RECIST criteria. Notably, baseline expression of PDGFR $\alpha$ did not correlate with response or time to progression. In order to utilize the phenomenon we have observed as a method for patient selection, one would need to monitor PDGFR $\alpha$ upregulation in tumor biopsy specimens or to develop a noninvasive or surrogate method to detect PDGFR $\alpha$ upregulation.

The evidence we provide represents a strong rationale to translate to a clinical setting the combinatorial strategy we have shown to be effective in counteracting the BRAF-I Gli1/PDGFR $\alpha$-mediated resistance of melanoma cells both in vitro and in vivo. The translation of this approach into the clinic is facilitated by the availability of Food and Drug Administration (FDA) approved drugs to use in combination. Furthermore, these data suggest that PDGFR $\alpha$ may be a useful biomarker to identify patients with BRAF-mutant melanoma who will or will not respond to BRAF-I or combination BRAF-I and MEK-I. Lastly PDGFR $\alpha$ up-regulation has therapeutic implications since BRAF(V600E) melanoma patients with PDGFR $\alpha$ up-regulation may potentially benefit from treatment with BRAF-I in combination with PDGFR $\alpha-\mathrm{I}$ or Shh-I.

\section{METHODS}

\section{Cell cultures}

The parental BRAF(V600E) melanoma cell lines Colo38 and M21 were cultured in RPMI 1640 medium (Mediatech) supplemented with $2 \mathrm{mmol} / \mathrm{L} \mathrm{L}$-glutamine (Mediatech) and 10\% fetal calf serum (FCS; Atlanta Biologicals). The cell lines M21 and Colo38 were originated by the late Dr. Donald Morton (when he was at the University of California) and by the late Dr. George Moore (when he was at University of Colorado), respectively, from metastatic lesions of patients with melanoma. The BRAF(V600E) melanoma cell line TPF10-741 was cultured in DMEM (Mediatech) supplemented with $2 \mathrm{mmol} / \mathrm{L}$ L-glutamine and 10\% FCS. This cell line was started from a cutaneous metastasis of the melanoma patient TPF-10-741 who had developed BRAF-I resistance following treatment with vemurafenib. Melanoma cell lines with acquired vemurafenib resistance (Colo38R and M21R) were generated by propagating parental Colo38 and M21 cells in increasing concentrations of BRAF-I (up to $2 \mu \mathrm{M}$ ). At the end of 2 months, resistant cells were isolated from each of the two cell lines and cultured in RPMI 1640 medium supplemented with $2 \mathrm{mmol} / \mathrm{L}$ L-glutamine, 10\% FCS and $500 \mathrm{nM}$ vemurafenib. All cells were cultured at $37^{\circ} \mathrm{C}$ in a $5 \% \mathrm{CO}_{2}$ atmosphere.

\section{Chemical reagents, antibodies and shRNAs}

Vemurafenib was purchased from ChemieTek. Sunitinib, imatinib, crenolanib and LDE225 were purchased from Selleck Chemicals LLC. MTT was purchased from Sigma. p-AKT (Ser473)-, AKT-, p-PI3K p85 ( 4458$)-$, p-CRAF(S289/296/301)-, p-MEK 1/2 (S217/221)-, p-ERK 1/2 (Thr202/Tyr204)-, ERK1/2-, PDFGR $\beta-$, p-PDGFR $\alpha-$, PDGFR $\alpha-$, PTEN-, VEGFR2-, Cleaved Caspase-3 (Asp175)-, p-Histone H3 (Ser10), Gli1- and $\beta$-actin-specific monoclonal antibodies (mAbs) were purchased from Cell Signaling Technology. The calnexin-specific mAb TO-5 was developed and characterized as described [55]. PDGFR $\alpha$-specific shRNA and GFP-shRNA were provided by the- Vector Core Facility of the University of Pittsburgh Cancer Institute.

\section{Patient Samples}

Patients with metastatic melanoma harboring the BRAF(V600E) mutation (confirmed by genotyping) were enrolled in clinical trials with the BRAF-I (vemurafenib) or with the BRAF-I (dabrafenib) and MEK-I (trametinib) combination. Patients were consented for tissue acquisition per institutional review board (IRB)-approved protocol. Tumor biopsies were performed pre-treatment (day 0), at 10-14 days on treatment, and/or at the time of disease progression as defined by Response Evaluation Criteria In Solid Tumors (RECIST) if applicable. Formalin-fixed tissue was analyzed to confirm that viable tumor was present via hematoxylin and eosin (H\&E) staining.

\section{Cell proliferation and MTT assay}

Cells were plated in triplicate in 96-well microtiter plates at the density of $2.5 \times 10^{3}$ per well in 100 ul of RPMI 1640 or DMEM medium supplemented with $2 \%$ FCS and treated with vemurafenib and/or PDGFR $\alpha$-I (sunitinib, imatinib and crenolanib) and/or Shh-I LDE225. Dimethyl sulfoxide (DMSO) (vehicle of the drugs) concentration was maintained at $0.02 \%$ in all wells. Doses of drugs to be used in the combinatorial treatment were chosen based on their IC50 determined with the melanoma cell lines tested. Cell proliferation was evaluated at the indicated time points utilizing the MTT assay which was carried out as reported elsewhere [56]. Data are expressed as percent of inhibition or percent of proliferation of treated cells as 
compared to untreated control cells. All experiments were performed three independent times in triplicates.

\section{Western Blot analysis}

For sample preparation from cell lines, cells were seeded at the density of $1 \times 10^{5}$ per well in a 6-well plate in medium supplemented with $2 \%$ FCS and the indicated doses of each drug or their combinations at $37^{\circ} \mathrm{C}$ in a $5 \%$ $\mathrm{CO}_{2}$ atmosphere for up to $72 \mathrm{~h}$. The DMSO (vehicle of the drugs) concentration was maintained at $0.02 \%$ in all wells. Untreated cells were used as a control. Cells were collected and lysed in lysis buffer $[10 \mathrm{mM}$ Tris- $-\mathrm{HCl}$ (pH 8.2), 1\% NP40, 1 mM EDTA, 0.1\% bovine serum albumin (BSA), $150 \mathrm{mM} \mathrm{NaCl}$ ) containing 1/50 (vol/vol) of protease inhibitor cocktail (Calbiochem). For sample preparation from tumor xenografts, tumors were harvested from the mice when they were sacrificed and stored at $-80^{\circ} \mathrm{C}$. Proteins were extracted by homogenization in the presence of 2 to $5 \mathrm{ml}$ lysis buffer. Western blot assay for signaling-related proteins was carried out as described [57]. The investigator who analyzed the sample from tumor xenografts was blinded to the type of treatment received by the mice used as the source of the tumor.

\section{RT-PCR}

Total RNA was isolated from melanoma cells using the RNeasy kit (Qiagen). Reverse transcription was performed using SuperScript II Reverse Transcriptase (Invitrogen) followed by qPCR using Fast SYBR Green Master Mix (Applied Biosystems). The following primers were used: NRAS fragment from 41-312 fwd:GCCGCATGACTCGTGGTTC rev:TCAGTGCGCTTTTCCCAACA; BRAF fragment from 1526-1934 fwd:GCACCTACACCTCAGCAGTT rev:TGACTTCTGGTGCCATCCAC. Sequences were aligned to the human reference sequence using the ClustalW2 v2.1 algorithm.

\section{Transduction of melanoma cells with Lentiviral vectors encoding shRNA}

M21R and TPF-10-741 cells were seeded at the density of $6 \times 10^{4}$ per well in a 6-well plate and incubated in culture medium for $24 \mathrm{~h}$ at $37^{\circ} \mathrm{C}$ in a $5 \% \mathrm{CO}_{2}$ atmosphere prior to viral infection. Cells were transduced with PDGFR $\alpha$-specific shRNA lentiviral particles [Target sequence: CCAGCCTCATATAAGAAGAAA (\#1), CCAGCTTTCATTACCCTCTAT (\#2), CGGTGAAAGACAGTGGAGAT (\#3), CCCAACTTTCTТАТСCAACTT (\#4), CAATGGACTTACCCTGGAGAA (\#5)] (1 x $10^{6}$ per well) in presence of polybrene $(2 \mu \mathrm{g} / \mathrm{ml})$ as described elsewhere
[58]. Cells transduced with GFP-shRNA were used as a control. Following an $18 \mathrm{~h}$ incubation at $37^{\circ} \mathrm{C}$, culture medium was removed and replaced with fresh culture medium. Following an additional up to $72 \mathrm{~h}$ incubation at $37^{\circ} \mathrm{C}$, cells were analyzed for GFP expression under the microscope, split, enriched for infected cells by selection with puromycin $(2.5 \mathrm{ug} / \mathrm{ml})$ and collected for further analysis.

\section{Immunohistochemistry}

Patient biopsies and tumors generated in mice were formalin fixed and paraffin embedded and then used as substrates in immunohistochemical reactions. Five- $\mu \mathrm{m}$ thick xenograft tissue sections were fixed on silane-coated glass slides, deparaffinized, and subjected to antigen retrieval (Target retrieval solution, DAKO). Following blocking, slides from mice were incubated with Cleaved Caspase-3 (Asp175) and p-Histone H3 (Ser10) -specific $\mathrm{mAbs}$ overnight. Four- $\mu \mathrm{m}$ thick sections from patientderived samples were fixed on silane-coated glass slides, deparaffinized, and subjected to antigen retrieval (Target retrieval solution, DAKO). Sections were then incubated with PDGFR $\alpha$-specific mAb (sc-338, Santa Cruz) $(1: 400)$ overnight. All sections were then washed with PBS, and the primary antibody was amplified using the VECTASTAIN ABC Kit (Peroxidase rabbit IgG, Vector Laboratories, PK-4001). The detection of this antibody was performed with the DAB Peroxidase Substrate Kit from DAKO and the sections were counterstained with H\&E. Tissue from a human GIST and its lymphocyte infiltrate were used as a positive and a negative control, respectively, for PDGFR $\alpha$ expression. PDGFR $\alpha$ expression, as measured by the percentage of stained melanoma cells, in tumors harvested from BRAF-I treated patients either on treatment or at the time of disease progression, was compared to that in pretreatment tumors. Scores were recorded semiquantitatively as $1+, 2+, 3+$ and $4+$, when , $1-25 \%, 26-50 \%, 51-75 \%$ and $>75 \%$ of melanoma cells were stained, respectively. Mitotic and apoptotic tumor cells in the sections of primary tumors harvested from mice were detected by staining $\mathrm{p}$-Histone H3 (Ser 10) and Cleaved Caspase-3 proteins, respectively, and quantified by counting 5 random fields per section (magnification $\times 200$ ). Data are expressed as the mean number of mitotic or apoptotic tumor cells in each group. The number of mitotic and apoptotic tumor cells was counted by an investigator who was blinded to the type of treatment received by the mice from which tumors had been harvested. 


\section{Assessment by flow cytometry of apoptosis induction}

Apoptosis was detected by cytometric staining performed as described [59]. Briefly, apoptotic cells were identified by staining with Annexin $-\mathrm{V}$ and propidium iodide (PI) (BD Bioscience) for $15 \mathrm{~min}$ at room temperature. Flow cytometry data were analyzed using Summit v4.3 software (DAKO).

\section{In vivo studies}

C.B-17 SCID female mice (8-10 week old) were purchased from Taconic Farms, Inc. Parental and BRAF-I resistant cell lines M21 and M21R ( 1 x $10^{6}$ cells/mouse) were implanted subcutaneously in the right lateral flank of mice. A total of 20 SCID mice was challenged with each cell line. Body weight and tumor volume were measured twice per week. Tumor volume was measured by vernier caliper. Treatment was initiated 10 days after cell inoculation when the tumor developed and had a diameter of around $0.4 \mathrm{~cm}$. Doses of sunintib and imatinib were chosen based on data available in the literature $[26,27$, $31,33]$. To test vemurafenib and sunitinib combination, mice were randomly divided into 4 groups of 5 mice each. Mice in Group 1 were treated with vemurafenib (12.5 mg/ $\mathrm{kg} /$ twice per day [60]), those in Group 2 with sunitinib (20 $\mathrm{mg} / \mathrm{kg} /$ day)[22] and those in Group 3 with vemurafenib (12.5 mg/kg/twice per day) and sunitinib (20 mg/kg/ day) combination. Mice in Group 4 were left untreated as a reference for the natural course of the disease. To test vemurafenib and imatinib combination, mice were randomly divided into 4 groups of 5 mice each. Mice in Group 1 were treated with vemurafenib $(25 \mathrm{mg} / \mathrm{kg} /$ twice per day [60]), those in Group 2 with imatinib (100 $\mathrm{mg} / \mathrm{kg} /$ day)[23] and those in Group 3 with vemurafenib (25 $\mathrm{mg} / \mathrm{kg} /$ twice per day) and imatinib (100 mg/kg/ day) combination. Mice in Group 4 were left untreated as a reference for the natural course of the disease. To test vemurafenib and LD225 combination, mice were randomly divided into 4 groups of 5 mice each. Mice in Group 1 were treated with vemurafenib $(12.5 \mathrm{mg} / \mathrm{kg} /$ twice per day), those in Group 2 with LDE225 (40 mg/ $\mathrm{Kg}$ /day) [41], and those in Group 3 with vemurafenib (12.5 mg/kg/twice per day) plus LDE225 (40 mg/kg/day). Mice in Group 4 were left untreated as a reference for the natural course of the disease. Drugs were administered by oral gavage. When a tumor from untreated mice reached the maximum diameter as approved by the Institutional Animal Care and Use Committee (IACUC) all mice were sacrificed. Primary tumors and organs were collected for further analysis. Animal studies have been approved by the IACUC.

\section{Statistical analysis}

Averages, standard deviations, and unpaired $t$-test were calculated using MS-Excel. Data are shown as mean $\pm \mathrm{SD}$ of the results obtained in at least three independent experiments. Time of disease progression (time to progression) of BRAF-I treated patients was studied using the Kaplan-Meier method and difference between groups was calculated using the log-rank test. Differences between groups were considered significant when the $P$ value was $<0.05$. The asterisk $(*)$ indicates $P<0.05$.

\section{ACKNOWLEDGMENTS}

The authors wish to thank Mr. R. Poudel for his excellent technical assistance.

\section{GRANT SUPPORT}

This work was supported by PHS grants RO1CA138188, RO1CA110249 and P50CA121973 awarded by the National Cancer Institute, by a Fondazione Umberto Veronesi Post Doctoral Fellowship awarded by the Fondazione Umberto Veronesi, and by Susan Komen Post Doctoral Fellowship KG111486 awarded by the Susan G. Komen for the Cure Foundation.

\section{REFERENCES}

1. Brose MS, Volpe P, Feldman M, Kumar M, Rishi I, Gerrero R, Einhorn E, Herlyn M, Minna J, Nicholson A, Roth JA, Albelda SM, Davies H, Cox C, Brignell G, Stephens P, et al. BRAF and RAS mutations in human lung cancer and melanoma. Cancer research. 2002; 62(23):6997-7000.

2. Long GV, Menzies AM, Nagrial AM, Haydu LE, Hamilton AL, Mann GJ, Hughes TM, Thompson JF, Scolyer RA and Kefford RF. Prognostic and clinicopathologic associations of oncogenic BRAF in metastatic melanoma. Journal of clinical oncology : official journal of the American Society of Clinical Oncology. 2011; 29(10):1239-1246.

3. Wan PT, Garnett MJ, Roe SM, Lee S, Niculescu-Duvaz D, Good VM, Jones CM, Marshall CJ, Springer CJ, Barford D, Marais R and Cancer Genome P. Mechanism of activation of the RAF-ERK signaling pathway by oncogenic mutations of B-RAF. Cell. 2004; 116(6):855-867.

4. Karasarides M, Chiloeches A, Hayward R, NiculescuDuvaz D, Scanlon I, Friedlos F, Ogilvie L, Hedley D, Martin J, Marshall CJ, Springer CJ and Marais R. B-RAF is a therapeutic target in melanoma. Oncogene. 2004; 23(37):6292-6298.

5. Cohen C, Zavala-Pompa A, Sequeira JH, Shoji M, Sexton DG, Cotsonis G, Cerimele F, Govindarajan B, Macaron N and Arbiser JL. Mitogen-actived protein kinase activation is an early event in melanoma progression. Clinical cancer 
research : an official journal of the American Association for Cancer Research. 2002; 8(12):3728-3733.

6. Lopez-Bergami P. The role of mitogen- and stress-activated protein kinase pathways in melanoma. Pigment cell \& melanoma research. 2011; 24(5):902-921.

7. Flaherty KT, Puzanov I, Kim KB, Ribas A, McArthur GA, Sosman JA, O’Dwyer PJ, Lee RJ, Grippo JF, Nolop K and Chapman PB. Inhibition of mutated, activated BRAF in metastatic melanoma. The New England journal of medicine. 2010; 363(9):809-819.

8. Chapman PB, Hauschild A, Robert C, Haanen JB, Ascierto P, Larkin J, Dummer R, Garbe C, Testori A, Maio M, Hogg D, Lorigan P, Lebbe C, Jouary T, Schadendorf D, Ribas A, et al. Improved survival with vemurafenib in melanoma with BRAF V600E mutation. The New England journal of medicine. 2011; 364(26):2507-2516.

9. Sosman JA, Moon J, Tuthill RJ, Warneke JA, Vetto JT, Redman BG, Liu PY, Unger JM, Flaherty LE and Sondak VK. A phase 2 trial of complete resection for stage IV melanoma: Results of Southwest Oncology Group Clinical Trial S9430. Cancer. 2011.

10. Emery CM, Vijayendran KG, Zipser MC, Sawyer AM, Niu L, Kim JJ, Hatton C, Chopra R, Oberholzer PA, Karpova MB, MacConaill LE, Zhang J, Gray NS, Sellers WR, Dummer R and Garraway LA. MEK1 mutations confer resistance to MEK and B-RAF inhibition. Proceedings of the National Academy of Sciences of the United States of America. 2009; 106(48):20411-20416.

11. Nazarian R, Shi H, Wang Q, Kong X, Koya RC, Lee H, Chen Z, Lee MK, Attar N, Sazegar H, Chodon T, Nelson SF, McArthur G, Sosman JA, Ribas A and Lo RS. Melanomas acquire resistance to B-RAF(V600E) inhibition by RTK or N-RAS upregulation. Nature. 2010; 468(7326):973-977.

12. Johannessen CM, Boehm JS, Kim SY, Thomas SR, Wardwell L, Johnson LA, Emery CM, Stransky N, Cogdill AP, Barretina J, Caponigro G, Hieronymus H, Murray RR, Salehi-Ashtiani K, Hill DE, Vidal M, et al. COT drives resistance to RAF inhibition through MAP kinase pathway reactivation. Nature. 2010; 468(7326):968-972.

13. Poulikakos PI, Persaud Y, Janakiraman M, Kong X, $\mathrm{Ng} \mathrm{C}$, Moriceau G, Shi H, Atefi M, Titz B, Gabay MT, Salton M, Dahlman KB, Tadi M, Wargo JA, Flaherty KT, Kelley MC, et al. RAF inhibitor resistance is mediated by dimerization of aberrantly spliced BRAF(V600E). Nature. 2011; 480(7377):387-390.

14. Villanueva J, Vultur A, Lee JT, Somasundaram R, Fukunaga-Kalabis M, Cipolla AK, Wubbenhorst B, Xu X, Gimotty PA, Kee D, Santiago-Walker AE, Letrero R, D'Andrea K, Pushparajan A, Hayden JE, Brown KD, et al. Acquired resistance to BRAF inhibitors mediated by a RAF kinase switch in melanoma can be overcome by cotargeting MEK and IGF-1R/PI3K. Cancer cell. 2010; 18(6):683-695.

15. Wagle N, Emery C, Berger MF, Davis MJ, Sawyer A, Pochanard P, Kehoe SM, Johannessen CM, Macconaill
LE, Hahn WC, Meyerson M and Garraway LA. Dissecting therapeutic resistance to RAF inhibition in melanoma by tumor genomic profiling. Journal of clinical oncology : official journal of the American Society of Clinical Oncology. 2011; 29(22):3085-3096.

16. Corcoran RB, Dias-Santagata D, Bergethon K, Iafrate AJ, Settleman J and Engelman JA. BRAF gene amplification can promote acquired resistance to MEK inhibitors in cancer cells harboring the BRAF V600E mutation. Science signaling. 2010; 3(149):ra84.

17. Montagut C, Sharma SV, Shioda T, McDermott U, Ulman M, Ulkus LE, Dias-Santagata D, Stubbs H, Lee DY, Singh A, Drew L, Haber DA and Settleman J. Elevated CRAF as a potential mechanism of acquired resistance to BRAF inhibition in melanoma. Cancer research. 2008; 68(12):4853-4861.

18. Paraiso KH, Xiang Y, Rebecca VW, Abel EV, Chen YA, Munko AC, Wood E, Fedorenko IV, Sondak VK, Anderson AR, Ribas A, Palma MD, Nathanson KL, Koomen JM, Messina JL and Smalley KS. PTEN loss confers BRAF inhibitor resistance to melanoma cells through the suppression of BIM expression. Cancer research. 2011; 71(7):2750-2760.

19. Shi H, Kong X, Ribas A and Lo RS. Combinatorial treatments that overcome PDGFRbeta-driven resistance of melanoma cells to V600EB-RAF inhibition. Cancer research. 2011; 71(15):5067-5074.

20. Lito P, Pratilas CA, Joseph EW, Tadi M, Halilovic E, Zubrowski M, Huang A, Wong WL, Callahan MK, Merghoub T, Wolchok JD, de Stanchina E, Chandarlapaty S, Poulikakos PI, Fagin JA and Rosen N. Relief of profound feedback inhibition of mitogenic signaling by RAF inhibitors attenuates their activity in BRAFV600E melanomas. Cancer cell. 2012; 22(5):668-682.

21. Flaherty KT, Infante JR, Daud A, Gonzalez R, Kefford RF, Sosman J, Hamid O, Schuchter L, Cebon J, Ibrahim N, Kudchadkar R, Burris HA, 3rd, Falchook G, Algazi A, Lewis $\mathrm{K}$, Long GV, et al. Combined BRAF and MEK inhibition in melanoma with BRAF V600 mutations. The New England journal of medicine. 2012; 367(18):16941703.

22. Chow LQ and Eckhardt SG. Sunitinib: from rational design to clinical efficacy. Journal of clinical oncology : official journal of the American Society of Clinical Oncology. 2007; 25(7):884-896.

23. Buchdunger E, Zimmermann $J$, Mett $H$, Meyer $T$, Muller M, Druker BJ and Lydon NB. Inhibition of the $\mathrm{Abl}$ protein-tyrosine kinase in vitro and in vivo by a 2-phenylaminopyrimidine derivative. Cancer research. 1996; 56(1):100-104.

24. Dai J, Kong Y, Si L, Chi Z, Cui C, Sheng X, Mao L, Li S, Lian B, Yang R, Liu S, Xu X and Guo J. Largescale Analysis of PDGFRA Mutations in Melanomas and Evaluation of Their Sensitivity to Tyrosine Kinase Inhibitors Imatinib and Crenolanib. Clinical cancer research 
: an official journal of the American Association for Cancer Research. 2013.

25. Bender $\mathrm{C}$ and Ullrich A. PRKX, TTBK2 and RSK4 expression causes Sunitinib resistance in kidney carcinomaand melanoma-cell lines. International journal of cancer Journal international du cancer. 2012; 131(2):E45-55.

26. Yeramian A, Sorolla A, Velasco A, Santacana M, Dolcet X, Valls J, Abal L, Moreno S, Egido R, Casanova JM, Puig S, Vilella R, Llombart-Cussac A, Matias-Guiu X and Marti RM. Inhibition of activated receptor tyrosine kinases by Sunitinib induces growth arrest and sensitizes melanoma cells to Bortezomib by blocking Akt pathway. International journal of cancer Journal international du cancer. 2012; 130(4):967-978.

27. Zhang D, Hedlund EM, Lim S, Chen F, Zhang Y, Sun B and Cao Y. Antiangiogenic agents significantly improve survival in tumor-bearing mice by increasing tolerance to chemotherapy-induced toxicity. Proceedings of the National Academy of Sciences of the United States of America. 2011; 108(10):4117-4122.

28. Kujawski M, Zhang C, Herrmann A, Reckamp K, Scuto A, Jensen M, Deng J, Forman S, Figlin R and Yu H. Targeting STAT3 in adoptively transferred $\mathrm{T}$ cells promotes their in vivo expansion and antitumor effects. Cancer research. 2010; 70(23):9599-9610.

29. Blansfield JA, Caragacianu D, Alexander HR, 3rd, Tangrea MA, Morita SY, Lorang D, Schafer P, Muller G, Stirling D, Royal RE and Libutti SK. Combining agents that target the tumor microenvironment improves the efficacy of anticancer therapy. Clinical cancer research : an official journal of the American Association for Cancer Research. 2008; 14(1):270-280.

30. Sims JT, Ganguly SS, Bennett H, Friend JW, Tepe J and Plattner R. Imatinib reverses doxorubicin resistance by affecting activation of STAT3-dependent NF-kappaB and HSP27/p38/AKT pathways and by inhibiting ABCB1. PloS one. 2013; 8(1):e55509.

31. Klosowska-Wardega A, Hasumi Y, Ahgren A, Heldin CH and Hellberg C. Combination therapy using imatinib and vatalanib improves the therapeutic efficiency of paclitaxel towards a mouse melanoma tumor. Melanoma research. 2010.

32. Pirraco A, Coelho P, Rocha A, Costa R, Vasques L and Soares R. Imatinib targets PDGF signaling in melanoma and host smooth muscle neighboring cells. Journal of cellular biochemistry. 2010; 111(2):433-441.

33. Triozzi PL, Aldrich W and Dombos C. Differential effects of imatinib mesylate against uveal melanoma in vitro and in vivo. Melanoma research. 2008; 18(6):420-430.

34. Ogawa Y, Kawamura T, Furuhashi M, Tsukamoto K and Shimada S. Improving chemotherapeutic drug penetration in melanoma by imatinib mesylate. Journal of dermatological science. 2008; 51(3):190-199.

35. Dai J, Kong Y, Si L, Chi Z, Cui C, Sheng X, Mao L,
Li S, Lian B, Yang R, Liu S, Xu X and Guo J. Largescale Analysis of PDGFRA Mutations in Melanomas and Evaluation of Their Sensitivity to Tyrosine Kinase Inhibitors Imatinib and Crenolanib. Clinical cancer research : an official journal of the American Association for Cancer Research. 2013; 19(24):6935-6942.

36. Herrmann A, Kortylewski M, Kujawski M, Zhang C, Reckamp K, Armstrong B, Wang L, Kowolik C, Deng $\mathrm{J}$, Figlin $\mathrm{R}$ and $\mathrm{Yu} \mathrm{H}$. Targeting Stat3 in the myeloid compartment drastically improves the in vivo antitumor functions of adoptively transferred $\mathrm{T}$ cells. Cancer research. 2010; 70(19):7455-7464.

37. Xie J, Aszterbaum M, Zhang X, Bonifas JM, Zachary C, Epstein E and McCormick F. A role of PDGFRalpha in basal cell carcinoma proliferation. Proceedings of the National Academy of Sciences of the United States of America. 2001; 98(16):9255-9259.

38. Ruiz i Altaba A, Sanchez P and Dahmane N. Gli and hedgehog in cancer: tumours, embryos and stem cells. Nature reviews Cancer. 2002; 2(5):361-372.

39. Stecca B, Mas C, Clement V, Zbinden M, Correa R, Piguet V, Beermann F and Ruiz IAA. Melanomas require HEDGEHOG-GLI signaling regulated by interactions between GLI1 and the RAS-MEK/AKT pathways. Proceedings of the National Academy of Sciences of the United States of America. 2007; 104(14):5895-5900.

40. Ruiz i Altaba A, Mas C and Stecca B. The Gli code: an information nexus regulating cell fate, stemness and cancer. Trends in cell biology. 2007; 17(9):438-447.

41. Fendrich V, Wiese D, Waldmann J, Lauth M, Heverhagen AE, Rehm J and Bartsch DK. Hedgehog inhibition with the orally bioavailable Smo antagonist LDE225 represses tumor growth and prolongs survival in a transgenic mouse model of islet cell neoplasms. Annals of surgery. 2011; 254(5):818-823; discussion 823.

42. Andrae J, Gallini R and Betsholtz C. Role of plateletderived growth factors in physiology and medicine. Genes \& development. 2008; 22(10):1276-1312.

43. Agaram NP, Wong GC, Guo T, Maki RG, Singer S, Dematteo RP, Besmer P and Antonescu CR. Novel V600E BRAF mutations in imatinib-naive and imatinib-resistant gastrointestinal stromal tumors. Genes, chromosomes \& cancer. 2008; 47(10):853-859.

44. Agaimy A, Terracciano LM, Dirnhofer S, Tornillo L, Foerster A, Hartmann A and Bihl MP. V600E BRAF mutations are alternative early molecular events in a subset of KIT/PDGFRA wild-type gastrointestinal stromal tumours. Journal of clinical pathology. 2009; 62(7):613616.

45. Hostein I, Faur N, Primois C, Boury F, Denard J, Emile JF, Bringuier PP, Scoazec JY and Coindre JM. BRAF mutation status in gastrointestinal stromal tumors. American journal of clinical pathology. 2010; 133(1):141-148.

46. Miranda C, Nucifora M, Molinari F, Conca E, Anania MC, 
Bordoni A, Saletti P, Mazzucchelli L, Pilotti S, Pierotti MA, Tamborini E, Greco A and Frattini M. KRAS and BRAF mutations predict primary resistance to imatinib in gastrointestinal stromal tumors. Clinical cancer research : an official journal of the American Association for Cancer Research. 2012; 18(6):1769-1776.

47. Straussman R, Morikawa T, Shee K, Barzily-Rokni M, Qian ZR, Du J, Davis A, Mongare MM, Gould J, Frederick DT, Cooper ZA, Chapman PB, Solit DB, Ribas A, Lo RS, Flaherty KT, et al. Tumour micro-environment elicits innate resistance to RAF inhibitors through HGF secretion. Nature. 2012; 487(7408):500-504.

48. Cheung M, Sharma A, Madhunapantula SV and Robertson GP. Akt3 and mutant V600E B-Raf cooperate to promote early melanoma development. Cancer research. 2008; 68(9):3429-3439.

49. Chappell WH, Steelman LS, Long JM, Kempf RC, Abrams SL, Franklin RA, Basecke J, Stivala F, Donia M, Fagone P, Malaponte G, Mazzarino MC, Nicoletti F, Libra M, Maksimovic-Ivanic D, Mijatovic S, et al. Ras/Raf/MEK/ ERK and PI3K/PTEN/Akt/mTOR inhibitors: rationale and importance to inhibiting these pathways in human health. Oncotarget. 2011; 2(3):135-164.

50. Atefi M, von Euw E, Attar N, Ng C, Chu C, Guo D, Nazarian R, Chmielowski B, Glaspy JA, Comin-Anduix B, Mischel PS, Lo RS and Ribas A. Reversing melanoma cross-resistance to BRAF and MEK inhibitors by cotargeting the AKT/mTOR pathway. PloS one. 2011; 6(12):e28973.

51. Greger JG, Eastman SD, Zhang V, Bleam MR, Hughes AM, Smitheman KN, Dickerson SH, Laquerre SG, Liu $\mathrm{L}$ and Gilmer TM. Combinations of BRAF, MEK, and $\mathrm{PI} 3 \mathrm{~K} / \mathrm{mTOR}$ inhibitors overcome acquired resistance to the BRAF inhibitor GSK2118436 dabrafenib, mediated by NRAS or MEK mutations. Molecular cancer therapeutics. 2012; 11(4):909-920.

52. Su F, Bradley WD, Wang Q, Yang H, Xu L, Higgins B, Kolinsky K, Packman K, Kim MJ, Trunzer K, Lee RJ, Schostack K, Carter J, Albert T, Germer S, Rosinski J, et al. Resistance to selective BRAF inhibition can be mediated by modest upstream pathway activation. Cancer research. 2012; 72(4):969-978.

53. Deng W, Gopal YN, Scott A, Chen G, Woodman SE and Davies MA. Role and therapeutic potential of PI3K-mTOR signaling in de novo resistance to BRAF inhibition. Pigment cell \& melanoma research. 2012; 25(2):248-258.

54. Sanchez-Hernandez I, Baquero P, Calleros L and Chiloeches A. Dual inhibition of (V600E)BRAF and the $\mathrm{PI} 3 \mathrm{~K} / \mathrm{AKT} / \mathrm{mTOR}$ pathway cooperates to induce apoptosis in melanoma cells through a MEK-independent mechanism. Cancer Lett. 2012; 314(2):244-255.

55. Ogino $\mathrm{T}$, Wang $\mathrm{X}$, Kato $\mathrm{S}$, Miyokawa N, Harabuchi $\mathrm{Y}$ and Ferrone S. Endoplasmic reticulum chaperonespecific monoclonal antibodies for flow cytometry and immunohistochemical staining. Tissue antigens. 2003;
62(5):385-393.

56. Yu L, Favoino E, Wang Y, Ma Y, Deng X and Wang X. The CSPG4-specific monoclonal antibody enhances and prolongs the effects of the BRAF inhibitor in melanoma cells. Immunologic research. 2011; 50(2-3):294-302.

57. Wang X, Osada T, Wang Y, Yu L, Sakakura K, Katayama A, McCarthy JB, Brufsky A, Chivukula M, Khoury T, Hsu DS, Barry WT, Lyerly HK, Clay TM and Ferrone S. CSPG4 protein as a new target for the antibody-based immunotherapy of triple-negative breast cancer. Journal of the National Cancer Institute. 2010; 102(19):1496-1512.

58. Tang JB, Goellner EM, Wang XH, Trivedi RN, St Croix CM, Jelezcova E, Svilar D, Brown AR and Sobol RW. Bioenergetic metabolites regulate base excision repairdependent cell death in response to DNA damage. Mol Cancer Res. 2010; 8(1):67-79.

59. Vermes I, Haanen C, Steffens-Nakken $\mathrm{H}$ and Reutelingsperger C. A novel assay for apoptosis. Flow cytometric detection of phosphatidylserine expression on early apoptotic cells using fluorescein labelled Annexin V. Journal of immunological methods. 1995; 184(1):39-51.

60. Yang H, Higgins B, Kolinsky K, Packman K, Go Z, Iyer R, Kolis S, Zhao S, Lee R, Grippo JF, Schostack K, Simcox ME, Heimbrook D, Bollag G and Su F. RG7204 (PLX4032), a selective BRAFV600E inhibitor, displays potent antitumor activity in preclinical melanoma models. Cancer research. 2010; 70(13):5518-5527. 